UDC $633.13+632.952$

\title{
BIOLOGICAL AGENTS TO PROTECT OATS AGAINST DISEASES IN RIGHT- BANK FOREST STEPPE UKRAINE
}

\author{
S. V. Retman, Yu. S. Panchenko \\ Institute of Plant Protection, NAAS, Kyiv, Ukraine, \\ e-mail: panchenko_yurij@i.ua
}

Species composition of oats diseases in the Right-bank Forest-steppe of Ukraine has been clarified. Results of application of biological fungicides by the method of seed dressing and surface treatment for the protection of tunicate (Chernihivskyi 28 variety) and hull-less (Samuel variety) oats are provided.

Key words: tunicate oats, hull-less oats, pathogen, biological fungicides, efficiency, yield.

Common oat (Avena sativa L.) is one of the crops that are crucial for increasing grain production. In Ukraine, it is grown mainly in the Forest-steppe and Polissia (gross harvest of grain is 499 thousand tons, yield is $2.4 \mathrm{t} / \mathrm{ha}$ ). The largest crop areas were in Volyn (39.5 thousand ha), Zhytomyr (30.4 thousand ha), Chernihiv (28.0 thousand ha), Rivne (21.2 thousand ha), Lviv (16.2 thousand ha) regions.

In recent years, due to increased heat supply during the growing season and violations of growing technologies, the phytosanitary state of crops, including oats, has deteriorated significantly. The following diseases damage culture crops.

Covered (stinking) smut; pathogen - Ustilago korelli Wille. The disease is widespread, manifested in the period of throwing comfrey, in which all the grains are black. The plant is affected during germination of seeds from gem and germinating teliospores on its surface. Type of infection - intermediate or external $[1,2,6]$.

Dust smut; pathogen - Ustilago avenae (Pers.) Rostrup. The disease manifests in the period of throwing comfrey, in which all the elements of the flower and set have the form of black-olive mass of spores. The main source of infection is seeds with hemes under the films. Infection of plants occurs in the soil during germination, despite the fact that the contamination with spores and some development of the mycelium under the films occurs during the flowering of plants. Harmfulness of the disease is due to the reduction of the similarity of the seeds and the density of planting. Shortfall of smuts diseases in some countries can reach $70 \%[1,2,6]$.

Steam rust; pathogen - Puccinia graminis (Pers.) Pers. f.sp. avenae. The disease is widespread in Polissia and in the western regions of the Forest-steppe; it manifests in the flowering phase - milk ripeness of grain on the stems, leaf sheaths, awns, and spike scales in the form of rust- 
brown, elongated pads of uridinies with uridine spores, which are placed on the plant in the form of brown torn bands. The harmfulness of stem rust is due to impaired water balance of plants (enhanced transpiration). In case of the epiphytotic development of the disease, the causative agent forms up to 0.5 uridine spores per 1 hectare of crops $(300 \mathrm{mln}$ pieces is in $1 \mathrm{~g})$. Upon the severe development of the disease, shortfall of the crop, due to so-called leakage of grain, can reach $70 \%$. Its quality also worsens: the content of asparagine and glutamic acid in the grains decreases. The main source of infection is seeds with hemes under the films. Infection of plants occurs in the soil during germination, despite the fact that the contamination with spores and some development of the mycelium under the films occurs during the flowering of plants $[1,2,6]$.

Crown rust; pathogen - Puccinia coronata Corda. It is spread in all growing zones, mostly in the Forest-steppe. In favourable years, the distribution reaches $100 \%$, and development $-53.6 \%$. The massive manifestation of the disease on plants is observed in the phase of flowering-filling of grain. Powdery, orange, rounded uridinies forms on the leaves, leaf sheaths, stems, and spike scales, later black teliopustules are formed around them, which remain under the epidermis. During the summer, the fungus can give 2-3 generations of uridine spores; the pathogen has no self-protection mechanism known for other rusty fungi. The number of pustules increases with increasing spore concentration to $1250 / \mathrm{cm}^{2}$, and there is no tendency for stabilization. Epiphytotic development of the disease can cause the death of plants within 23 days from the time of the appearance of the first single of uridinies. Upon the severe damage to the plants, the feeble grain is formed, its quality deteriorates, yields decrease to $70 \%$, and under favourable weather conditions direct losses can reach $100 \%$ [1, 2, 3-6].

Mildew; pathogen -Blumeria graminis DC f.sp. avenae Em. Marchal (syn. Erysipharmic DC .f. tritici Em. Marchal). The disease manifests during the vegetation of plants. On the seedling, it first appears on the sheath of the leaves in the form of matte spots, and later in the form of a white loose plaque, which is sealed and converted into wadded pads. Plaque spreads on a leafy plate, often from the upper, and sometimes from both sides. With the growth of plants, plaque spreads on stems, leaves, leaf sheaths, and spires. The pathogen forms a conical sporulation and ascogenous stage. Infection of plants occurs at a temperature of $0-20{ }^{\circ} \mathrm{C}$ and relative humidity of air of 50$100 \%$. High air temperature (over $30{ }^{\circ} \mathrm{C}$ ) retards the development of mildew. Harmfulness of the disease is due to the reduction in the assimilation surface of the leaves, the destruction of chlorophyll and other pigments, as a result of which the intensity of photosynthesis decreases. In the case of intense damage, the development of the root system is slowed down, the productive planting of the plants decreases, the ejection delays, and maturation accelerates. Shortfall of crop from the disease is $10-15 \%[1,2,6]$. 
Red-brown spotting or helminthosporiose; pathogen - Pyrenophora avenae Itoet. Kurib. (anamorph: Dreshlera avenae (Eidam) Sharif). The main source of infection is the mycelium and conidia of the fungus on the affected remnants and in the form of conidia on the grain. An additional source - the affected remnants, which retain the perithecia of the fungus. Conidia are grown in the temperature range of $5-33^{\circ} \mathrm{C}$ (optimum $18-24^{\circ} \mathrm{C}$ ) and air humidity above $96 \%$. The incubation period of the disease development at optimal temperature lasts for 5 days. The disease is widespread, especially harmful in the Forest-steppe; appears on the leaves in the form of darkbrown, dark-gray, or brown-red, oblong, fibre-limited spots. In the wet weather, dark-oily plaque appears on them, which is the conidial sporulation of the pathogen of the disease. The affected leaves dry and prematurely die. In case of severe lesion (sometimes up to $75 \%$ ), feeble grains are formed, and shortfall is more than $10 \%[1-4,6]$.

Leaf blotch; pathogen - Phaeosphaeria avenaria (G.F.Weber) O.Eriksson f.sp. avenae (Stagnospora avenae (A.B.Frank) Bisset). The disease manifests on the leaves, sheath, stem, and spike scales, first in the form of small chlorotic spots, which later become oblong. The damaged tissue lightens in the center of the spots, and a brown rim is formed on the edge of a healthy and damaged tissue. On the affected tissue, there are numerous black dots - pycnidia of the pathogen. The affected leaves are necrotized and die. On the stems of the plants, the spots are first light, then blacken and become shiny. In these places, the stem putrefies and breaks out. The disease mostly develops in wet weather in the second half of vegetation, but sometimes it also appears on sprouting (the damage can reach $15 \%$ ). Harmfulness of the disease is due to the deterioration of the main parameters of the structure of the crop. Shortfall of crop can reach $20 \%$ or more $[1,2,6,10]$.

Brown spotting or heterosporium disease; pathogen - Heterosporium avenae Oudem. The disease manifests on the leaves in the form of fallow or brown spots, on which dark turfs - conidial sporulation of the fungus - are placed by the longitudinal lines. Harmfulness of the disease, like all other spotting in oats, is manifested in premature death of affected leaves, reduction of plant productivity $[1,2,6]$.

Ordinary root rot; pathogen - Cochliobulus sativus (Itoet Kurib.) Drechslet Dastur (anamorph: Drechslera sorociniana Subram (syn. Bipolaris sorociniana Subram; Helmintisporium sativum P.K.et. B.)). The pathogen develops mainly in the conidial stage. The spread of infection is facilitated by windy and rainy weather (the damage to plants can reach $17 \%$ ). Ascogenous (teliomorphic) stage in the pathogen development cycle is almost lost in the planting phase. At the beginning, small dark spots appear, which later expand to a length of $1.5 \mathrm{~cm}$, dark-brown or darkgray in the centre, pale at the edge. On the damaged tissues, black or olive-brown plaque of fungus sporulation is formed during wet weather. Ellipsoidal, light-brown to black spots are formed on the leaves during further stage of plant development, and in most cases they have a light rim and a clear 
border between healthy and damaged tissue. At the base of stem, upon mild disease development, it manifests in the form of dark-brown necrotic strips, colour of which gradually passes to a healthy tissue, that is, they do not have a clear boundary between healthy and damaged tissue. During the intensive development of the disease, the base of the steam blackens and putrefies down to the lower node of the stem $[1,2,6,10]$.

To protect oat from diseases, an integrated approach is needed for the development and implementation of protective measures, which follows from the concept of "integrated plant protection". An important factor in the "ecologization" of the protection systems is the use of environmentally safe means of protection, in particular biofungicides, which is relevant in the growing of oats, grain of which is a raw material for the production of products for children and dietary nutrition. These preparations immunize the plant by way of forming non-specific systemic resistance to pathogens and to a number of adverse environmental factors: drought, low and high temperatures. The preparations also have direct fungicidal action on the pathogens, they activate the growth processes in plants, contribute to the improvement of their mineral nutrition due to the nitrogen fixation from the air; transformation of insoluble forms of phosphates into a digestible form; reproduction, activation of the useful microflora [7, 8].

In connection with the above-mentioned, the objective of our study was to monitor the phytosanitary state of oat crops, clarify the species composition of pathogens, assess the effectiveness of biofungicides under different technological methods of application and determination of and crop yields.

Materials and methods. The study was carried out in 2015-2016 at the experimental plots of the State Enterprise Experimental Base "Oleksandria" (Right-Bank Forest-steppe), the size of plots was $25 \mathrm{~m}^{2}$, the placement of plots is randomized, the repetition is four-time. Chaffy oat (A. sativa subsp. Sativa Rod. et Sold.) of Chernihivskyi 28 variety and naked oats (A. sativa subsp. nudi sativa (Husnot) Rod. et Sold.) of Samuel variety was sowed. Biofungicides Haupsyn (Pseudomonas aurefaciens B-111 and B-306, titre of viable cells is of $1 \times 10^{4}$ per $1 \mu \mathrm{g}$ of preparation) was applied for inoculation with a consumption rate $(\mathrm{CR})$ of $6 \mathrm{~L} / \mathrm{t}$; for surface treatment (on the leave) with $\mathrm{CR}$ of $4 \mathrm{~L} / \mathrm{ha}$ and Phitocyd (Bacillus subtilis at the amount of (1-9) $\times 10^{9} \mathrm{CFU} / \mathrm{cm}^{3}$ ) for seed bacterization with $\mathrm{CR}$ of $1.5 \mathrm{~L} / \mathrm{t}$. Determination of the degree of disease development, technical effectiveness of preparations and yield of culture were carried out according to generally accepted methods [9].

To determine the intensity of the disease development (R, \%), the average percentage of disease development was calculated according to the formula:

$$
R=\frac{\sum n \times b}{N \times 4} 100,
$$

where 
$n$ - number of diseased plants (pcs),

$N$ - total number of accountable plants (pcs),

$b$ - appropriate involvement score

$\sum n \times b-$ sum of products of the number of plants on the corresponding involvement score, 4 - the highest score of the 5-point scale.

Species of pathogens was determined according to the cultural and morphological features [2, 10-13]:

Puccinia coronata Corda: aeciospores are multifaceted, spherical, 16-24 x 12-18 $\mu \mathrm{m}$. Uridinies are of 0.2-0.6 mm long, powdery, orange, spherical (14-26 x 12-18 $\mu \mathrm{ms})$ with a long, scabrous shell. Teliospores of different shapes, predominantly clavate (32-64 x 12-24 $\mu \mathrm{m}$ ) with a thickened sheath on top of up to $3.5 \mu \mathrm{m}$, with corona-like germs.

Blumeria graminis DC f.sp. avenae Em. Marchal (syn. Erysiphegra minis DC. F. tritici Em Marchal): conidia are single-celled, colourless, cylindrical or barrel-shaped, of 25-30 x 8-10 $\mu \mathrm{m}$ in size, placed in chains on single-celled, slightly elongated conidiophores. Ascogenous stage of the fungus is characterized by the formation of cleistocarp with ascus and ascospore on mycelium. Cleistocarps are round, initially brown, and eventually black, 135-180 $\mu \mathrm{m}$ in diameter, have a small number of light, short appendages. They have several asci of 70-100 x 25-40 $\mu \mathrm{m}$ in size. Each ascus contains 4-8 colourless elliptical ascospores of 20-23 x 11-13 $\mu \mathrm{m}$ in size.

Pyrenophora avenae Itoet Kurib. (anamorph: Dreshlera avenae (Eidam) Sharif): conidiophores are chimneys, cylindrical, thickened at the base, up to $200 \mu \mathrm{m}$ long and 9-12 $\mu \mathrm{m}$ in thickness. The conidia are light-olive, cylindrical, slightly thickened in the middle, and they are rounded near the top with 3-8 transverse membranes, smooth with thick sheath (8-110 x 15-20 $\mu \mathrm{m})$.

Phaeosphaeria avenaria (G.F.Weber) O.Eriksson f.sp. avenae (Stagonospora avenae (A.B.Frank) Bisset): pycnida are spherical, black, with a diameter of 40-140 $\mu \mathrm{m}$. Pycnospores are colourless, cylindrical, straight or slightly curved (20-45 x 3-4 $\mu \mathrm{m})$ have 2-5 transverse membranes. Conidia are colourless, sticky, straight or curved, 20-45 x 3-4 $\mu \mathrm{m}$, with three membranes.

Cochliobulus sativus (Itoet Kurib.) Drechslet Dastur (anamorph: Drechslera sorociniana Subram (syn. Bipolaris sorociniana Subram; Helmintisporium sativum P.K. et B.)): mycelium of the pathogen is dark-coloured; conidiophores are single or collected in groups of 2-3 kneed olive (up to $130 \mu \mathrm{m}$ in length); forms conidia on the tops. They are dark-olive, egg or spindle-shaped, sometimes curved, with 3-13 transverse membranes, 60-134 x 17-30 $\mu \mathrm{m}$ in size.

Heterosporium avenae Oudem: conidiophores are beam-shaped by 6-10 pieces, nodularcurved, multicellular. The conidia are originally unicellular, later two-cell, light-smoky, rounded at the ends, $18-35 \times$ 9-14 $\mu \mathrm{m}$ in size. 
Results and discussion. According to the results of monitoring of oat crops of both studied varieties during the growing season, ordinary root rot, mildew, red-brown spotting, crown rust, leaf blotch and heterosporium disease were found. It should be noted that the development of detected diseases in Chernihivskyi 28 variety was higher than that of Samuel variety, and it was (average for two years): for root rot - 25.0 and $17.5 \%$; for mildew - 46.6 and $37.2 \%$; for red-brown spotting 33.5 and $35.5 \%$; for crown rust -25.4 and $14,5 \%$, by varieties respectively (Table 1 and 2 ).

Table 1. Technical efficiency of biofungicides for inoculation of seeds, Chernihivskyi 28 variety

\begin{tabular}{|c|c|c|c|c|c|c|c|}
\hline \multirow[b]{2}{*}{$\begin{array}{l}\text { Variants of } \\
\text { experiment }\end{array}$} & \multicolumn{6}{|c|}{ Technical efficiency,\% } & \multirow[b]{2}{*}{ 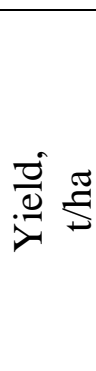 } \\
\hline & 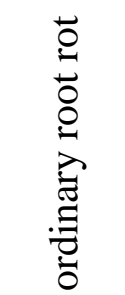 & $\begin{array}{l}\frac{0}{0} \\
0 \\
0 \\
0 \\
0 \\
0\end{array}$ & $\frac{z}{\frac{3}{0}}$ & 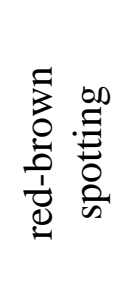 & 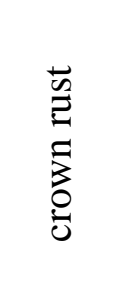 & 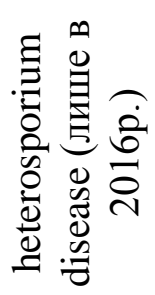 & \\
\hline Control* & $(25,0)$ & $(36,0)$ & $(46,6)$ & $(33,5)$ & $(25,4)$ & $(17,0)$ & 4,75 \\
\hline Haupsyn & 59,2 & 46,7 & 51,1 & 40,2 & 30,6 & 38,3 & 5,65 \\
\hline Phitocyd & 61,1 & 46,2 & 50,2 & 42,7 & 32,0 & 40,1 & 5,60 \\
\hline $\mathrm{LSD}_{05}$ & & & & & & & 0,31 \\
\hline
\end{tabular}

$*_{\text {- the disease in control }}$

Table 2. Technical efficiency of biofungicides for inoculation of seeds, Samuel variety

\begin{tabular}{|c|c|c|c|c|c|c|c|}
\hline \multirow[b]{2}{*}{$\begin{array}{l}\text { Variants of } \\
\text { experiment }\end{array}$} & \multicolumn{6}{|c|}{ Technical efficiency,\% } & \multirow[b]{2}{*}{ 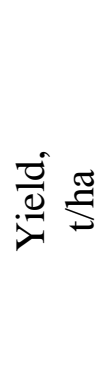 } \\
\hline & 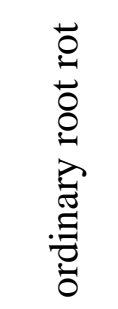 & 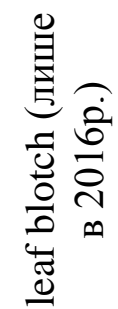 & $\frac{\frac{3}{0}}{\frac{0}{g}}$ & 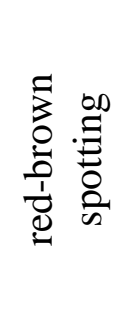 & 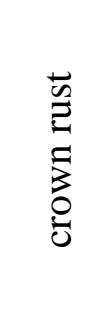 & 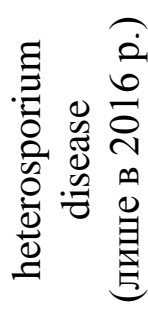 & \\
\hline Control* & $(17,5)$ & $(18,3)$ & $(37,2)$ & $(35,5)$ & $(14,5)$ & $(10,3)$ & 6,05 \\
\hline Haupsyn & 55,1 & 59,0 & 49,0 & 46,3 & 42,0 & 37,1 & 7,50 \\
\hline Phitocyd & 55,3 & 57,5 & 53,5 & 48,2 & 47,7 & 36,5 & 7,49 \\
\hline $\mathrm{LSD}_{0,5}$ & & & & & & & 1,10 \\
\hline
\end{tabular}

$*_{\text {- the disease in control }}$ 
The development of leaf blotch in Chernihivskyi 28 variety was $36.0 \%$ (average for two years), in Samuel variety - $18.3 \%$ (detected in 2016 only). Heterosporium disease was diagnosed in both varieties in 2016 only, and the degree of its development was 17.0 and $10.3 \%$.

Application of biofungicides Haupsyn and Phitocyd (upon seed treatment) provided the highest technical efficiency in both varieties against the ordinary root rot - 55.1-61.1\%; leaf blotch - 46.2-59.0\%; mildew 49.0-51.1\%. The effectiveness of the studied preparations against crown rust and heterosporium disease was the lowest $-30.6-47.7 \%$ and 36.5-40.1\%, respectively.

Upon the superficial treatment of oat crops by biofungicide Haupsyn, the highest technical efficiency was observed against heterosporium disease - up to $63.3 \%$; leaf blotch - up to $60.2 \%$; crown rust - up to $59.7 \%$; and the lowest against the red-brown spotting - up to $42.0 \%$ (Table 3, 4).

Table 3. Technical efficiency of biofungicide Haupsyn for surface treatment of plant (on leaf), Chernihivskyi 28 variety

\begin{tabular}{|c|c|c|c|c|c|c|}
\hline \multirow[b]{2}{*}{$\begin{array}{l}\text { Variants of } \\
\text { experiment }\end{array}$} & \multicolumn{5}{|c|}{ Technical efficiency,\% } & \multirow[b]{2}{*}{ 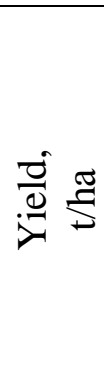 } \\
\hline & $\begin{array}{l}\frac{0}{0} \\
0 \\
0 \\
0 \\
0 \\
0\end{array}$ & $\frac{3}{0}$ & 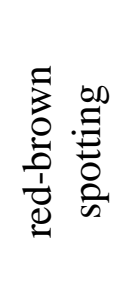 & 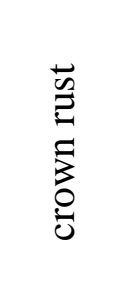 & 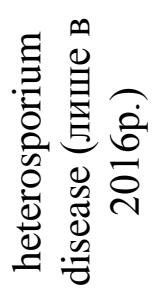 & \\
\hline Control* & $(36,0)$ & $(46,6)$ & $(33,5)$ & $(25,4)$ & $(17,0)$ & 4,75 \\
\hline Haupsyn & 60,2 & 46,3 & 42,0 & 59,7 & 63,3 & 5,25 \\
\hline $\mathrm{LSD}_{0,5}$ & & & & & & 0,50 \\
\hline
\end{tabular}

$*$ - the disease in control

Table 4. Technical efficiency of biofungicide Haupsyn for surface treatment of plant (on leaf), Samuel variety

\begin{tabular}{|c|c|c|c|c|c|c|}
\hline \multirow[b]{2}{*}{$\begin{array}{l}\text { Variants of } \\
\text { experiment }\end{array}$} & \multicolumn{5}{|c|}{ Technical efficiency, $\%$} & \multirow[b]{2}{*}{ 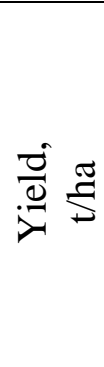 } \\
\hline & 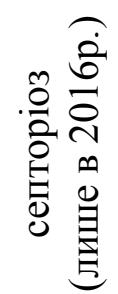 & $\frac{3}{\frac{z}{0}}$ & 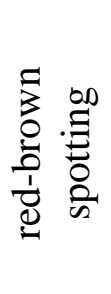 & 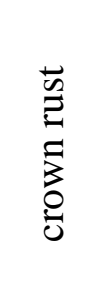 & 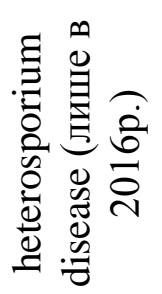 & \\
\hline Control* & $18,3 *$ & 37,2 & 35,5 & 14,5 & 10,3 & 6,05 \\
\hline Haupsyn & 57,3 & 51,8 & 40,3 & 40,2 & 54,1 & 7,10 \\
\hline $\mathrm{LSD}_{0,5}$ & & & & & & 0,70 \\
\hline
\end{tabular}


It should be noted that the effect of this biofungicide on the development of heterosporium disease was quite differentiated: upon treatment of seeds, it provided higher efficiency compared with superficial treatment.

The application of the studied biofungicides provided a higher yield on both varieties. The retained crop upon inoculation of seeds was 0.90-0.85 t/ha (18.9\%) for Chernihivskyi 28 variety and $1.45 \mathrm{t} / \mathrm{ha}(24.0 \%)$ for Samuel variety. Upon superficial treatment (on a leaves) by Haupsyn, the retained crop was at the level of $0.95 \mathrm{t} / \mathrm{ha}(15.7 \%)$.

Consequently, during the study period, crops of the chaffy and naked oat were damaged by: ordinary root rot (Cochliobulus sativus Itoet Kurib), leaf blotch (Phaeosphaeria avenaria (G. F. Weber) O.Eriksson f.sp. avenae (Stagonospora avenae (A. B. Frank) Bisset), mildew (Blumeria graminis DC f. sp. avenae Em Marchal), red-brown spotting (Pyrenophora avenae Itoet Kurib, anamorph: Dreshlera avenae (Eidam) Sharif), heterosporium disease (Heterosporium avenae Oudem), and crown rust (Puccinia coronata Corda), the development of which was 17.0$46.6 \%$ for Chernihivsky 28 variety and 10.3-37.2 \% for Samuel variety.

Biofungicides Haupsyn and Phitocyd showed the greatest efficiency against ordinary root rot, leaf blotch, and mildew (technical efficiency of 46.2-61.1\%) upon treatment of seeds at the CR of $6 \mathrm{~L} / \mathrm{t}$ and $1.5 \mathrm{~L} / \mathrm{t}$, respectively.

Technical efficiency of Haupsyn for superficial treatment with CR of $4 \mathrm{~L} / \mathrm{ha}$ was the highest against heterosporium disease, leaf blotch, and crown rust (up to 59.7-63.3\%).

The application of studied biofungicides to protect oats contributed to retain of crops at the level of $15.7-24.0 \%$.

The obtained results can be used to develop an effective and environmentally-oriented system for protecting the culture, especially for the production of children's and dietary nutrition. 
1. Марков І. Діагностика вівса / Іван Марков // Агробізнес. - 2014. - № 1-2. - С. $16-20$.

2. Марков І. Л.Практикум із сільськогосподарської фітопатології : навч.посіб. / І. Л. Марков. - К. : ННЦ ІАЕ, 2011. - С. 19-20.

3. Поплавская Н. Г. Патогенный комплекс грибов, паразитирующих на овсе (литературный обзор) / Н. Г. Поплавская // Защита растений : сборник научных трудов. 2012. - № 36. - C. 125-132.

4. Буга С. Ф. Защита овса от болезней / С. Ф. Буга, А. Г. Жуковский, Т. Н. Жердецкая // Защита растений : сборник научных трудов. — 2011. - № 35. - С. 85-98.

5. Куцак М. М. Поширення та розвиток корончастої іржі вівса у Лісостепу України / М. М. Куцак // Тези доп. конф. молодих учених "Екологічно обгрунтований захист рослин" (Київ, 4 - 7 жовтня 2005 р.). — К. : Колобіг, 2005. — С. 126-128.

6. Agrios Georg N. Plant Pathology/ Georg N. Agrios. - ACADEMIC PRESS, 2005. P. 300-348.

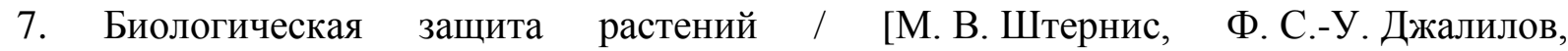
И. В. Андреева и др.]; под ред. М. В. Штернис. - М. : Колос, 2004. - С. 192-200.

8. Теслюк В. В. Концептуальні основи виробництва і застосування мікобіопрепаратів / Теслюк В. В. // Наукові доповіді НУБіП, 2011. - 7(23). - Режим доступу: http://www.nbuv.gov.ua/e-journals/Nd/2011_7/11tbbpam.pdf

9. Методика випробування і застосування пестицидів/ [С. О. Трибель, Д. Д. Сігарьова, М. П. Секун та ін.]; за ред. проф. С. О. Трибеля. - К. : Світ, 2001. - С.267-270.

10. Болезни сельскохозяйственных культур: в 3 т. [под ред. В. Ф. Пересыпкина]. - К. : Урожай. - Т. 1: Болезни зерновых и зернобобовых культур, 1989. - 216 с.

11. Степанов К. М. Ржавчина зерновых культур / К. М. Степанов. - Л. : Колос, 1975. $-72 \mathrm{c}$.

12. Визначник грибів України: в 5 т. [за ред. Д. К. Зерова]. - Том II Аскоміцети. - К. : Наукова думка, 1969. - 520 с.

13. Микроорганизмы - возбудители болезней растений / [Билай В. И., Гвоздяк Р. И., Скрипаль И. Г. и др.]; под ред. Билай В. И. - К. : Наукова думка, 1989. - С. 14-223. 
БИОЛОГИЧЕСКИЕ ПРЕПАРАТЫ

ДЛЯ ЗАЩИТЫ ОВСА ОТ БОЛЕЗНЕЙ

В ПРАВОБЕРЕЖНОЙ ЛЕСОСТЕПИ

УКРАИНЫ

Ретьман С.В., Панченко Ю.С.

Институт защиты растений НААН, г. Киев

Уточнен видовой состав болезней

овса в Правобережной Лесостепи

Украиньл. Представлены результатьл

применения биологических фунгицидов

способом протравливания семян $и$ поверхностной обработки для защиты овса пленочном (сорт Черниговский 28) и голозерного (сорт Самуэль).

Ключевые слова: овес пленочный, овес голозерний, возбудитель, биологические фунгициды
БІОЛОГІЧНІ ПРЕПАРАТИ ДЛЯ ЗАХИСТУ ВІВСА ВІД ХВОРОБ У ПРАВОБЕРЕЖНОМУ ЛІСОСТЕПУ УКРАЇНИ

\section{Ретьман С.В., Панченко Ю.С.}

Інститут захисту рослин НААН, м. Київ

Уточнено видовий склад хвороб вівса в Правобережному Лісостепу України. Висвітлено результати застосування біологічних фунгіциидів способом протравлювання насіння та поверхневої обробки для захисту вівса плівчастого (сорт Чернігівський 28) та голозерного (сорт Самуель).

Ключові слова: овес плівчастий, овес голозерний, збудник, біологічні фунгіщиди, ефективність, урожай.

эффрективность, урожай. 